\begin{tabular}{|cc|c|c|}
\hline International Journal of Trend in Scientific Research and Development (IJTSRD) \\
International Open Access Journal | www.ijtsrd.com \\
ISSN No: 2456 - 6470 | Volume - 2 | Issue - 6 | Sep - Oct 2018
\end{tabular}

\title{
Smart City Ranchi: A New Dimension of Urban Space
}

\author{
Animesh Gope ${ }^{1}$, Sangam Suman ${ }^{2}$ \\ ${ }^{1}$ Faculty, Department of Geography, Doranda College, Ranchi University, Ranchi, Jharkhand, India \\ ${ }^{2}$ Research Scholar, Department of Geography, Patna University, Patna, Bihar, India
}

\begin{abstract}
The paper try to analyze the viability and sustainability of Ranchi as a 'Smart City'. At present Ranchi has 16.5 lac. Urban population (2011), about $43.14 \%$ of the total population of the district. In order meet the demands of this rapidly increasing neo middle class urban population. Ranchi as 'Smart City' is a great initiative. The papers illustrate the current status of Ranchi city and its urban issues along with the solution in two heads, Area Based Development (ABD) and Pan City Project under Smart city Ranchi mission.
\end{abstract}

Also some of the existing smart cities of the world and India have been discussed to understand the better perspective of the smart city in context of Ranchi.

Keyword: Smart City, ABD, Pan City Project, Urban, ICT.

\section{INTRODUCTION}

The city started becoming 'smart' back in 1920, when the world first automated traffic light were installed in Houston Texas (USA). In India the concept of smart city is coined out by Indian Prime Minister in June 2014.when he announced a plan of 100 smart cities in India. Cities in the past were built on river banks, they are now built along highways but in future they will be built best on availability of 'Optical Fiber' networks and next generation infrastructure claimed by P.M. Narendra Modi.

The 'smart city' concept integrates information and communication technology and various physical devices connected to the network, to optimize the efficiency of the city operation and services and connect to citizens.

A city considered 'smart city' if it exhibits the ability to keep track of state of its environment and activities of its citizens and use the information obtained to provide better serviced such as greater automation, intelligent routing and transportation, better monitoring, and better city management.

'Smart City' refers to smart infrastructure for environment and social sustainability.

\section{STUDY AREA}

The study area taken is the capital city of Jharkhand namely known as 'Ranchi'. Which is located between $23^{\circ} 25^{\prime}$ Nto $23^{\circ} 27^{\prime} \mathrm{N}$. Latitudeand the longitudinal extension is $85^{\circ} 20^{\prime} \mathrm{E}$ to $85^{\circ} 23^{\prime} \mathrm{E}$. It has an average height of $643.6 \mathrm{M}$ above sea level. It has area of 5,097sq.km. Possesses 3rd rank in area within the state. The city comprises total population of 2,914,253 according to 2011 census ranks first among the state districts. The Population density is 572person per square kilometer.sex ratio is as same as of the state 949 female after 1000 males.

The study area comprises area based development (ABD) and Pan City development project which is shown in the figure below.

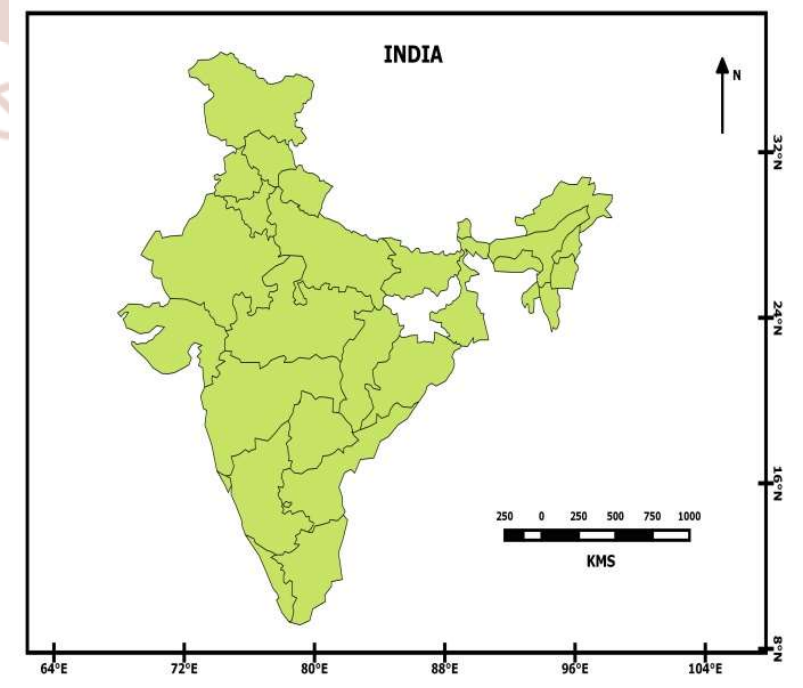




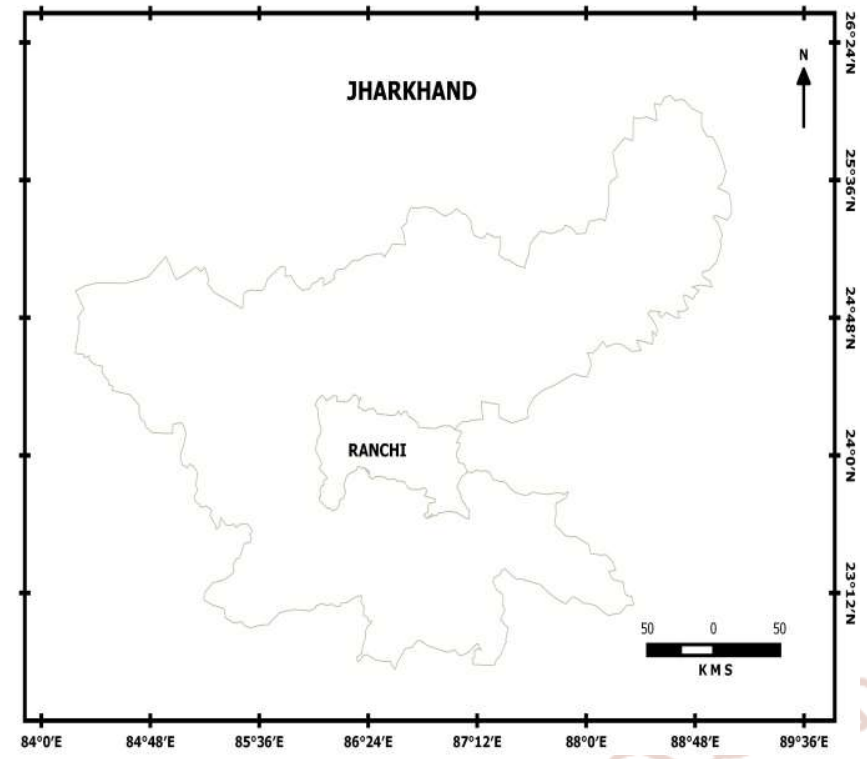

\section{RESEARCH PROBLEM}

\section{Economy problem}

A. Migration in flow cause informal employment result into exploitation.

B. Under employment or unemployment cause crime, drug abuse, alcoholism.

C. Municipal in sufficient fund result into poor civic amenities.

\section{Environmental Problem}

A. High rents in CBD compel people to live in peripheral area increase public transportation result in air pollution.

B. Energy crisis results into the compulsion use of diesel generator in shopping malls causing pollution.

Social Problem: Slum growth, poor sewage, diseases, poverty.

\section{OBJECTIVES}

The paper attempted to analyse how viable and effective Ranchi Smart City would be to resolve the problem arising in urban space of Ranchi like: Congestion, Traffic environment population in flow of migration, slum and Rehabilitation of displaced people.

\section{METHODOLOGY}

In order to analysis the paper we used the secondary data obtained from the various sources like data from official website of Smart City Government of India, official website of Urban development and Housing Department. of Jharkhand. Also referred some books and Journal, Hand book of Ranchi, 2011.

\section{NEEDS FOR SMART CITY}

The concept of Smart City is nothing but sophisticating the exited cities. It is a process of renewal of urban space.

The essence of Smart Cities lies in the capturing a real time data as well as its intelligent processing that enable $\mathrm{s}$ various application area ranging from managing environment quality and the built environment to land use and transportation planning .Smart Cities are the future to sustainability to support population growth and urban expansion .

In India 34cr. Population living in urban area and their share in GDP is about $60 \%$ in 2008 . Which over a period of time increase by $82 \%$ share in GDP by $37.71 \mathrm{cr}$. Population living in urban space of India in 2011. The demand for every civic amnestic to raised by 5 to 7 times. Specially by neo middle class. Neosatellite town mid size cities required to accommodate these neo middle class and migrated population from rural to urban. In this smart city will play a very crucial role in accommodating the emerging neo middle class population.

In Ranchi the share of urban population was 9.7 lac in total population in 2001 which has increased by 16.5 lac in 2011 which consist of about $43.14 \%$ of total population of Ranchi. The share of these urban populations in secondary and tertiary activities is about $49 \%$, to demand of such a huge urban population, Ranchi as a smart city will be a major thrust.

Although the problem of out migration in over all Jharkhand pre dominants according to economic survey of India 2011, 5 million working is population from 2001-2011 migrated outside the state. More than $5 \%$ working is population annually migrates to other states in search of better employment, education, etc. the largest proportion of out migration from the state is from Dhanbad, Lohardaga, Gumla.

However the scenario in Ranchi is different being a capital city of the state a huge proportion of inflow of migration takes place for the better employment, education and to enjoy other urban facilities possesby the city. 
PRESENT SCINARIO OF THE VARIOUS COMPONENTS OF URBAN CITY RANCHI

Energy: $90.34 \%$ of urban households enjoying electricity facility in the urban space of Ranchi where as $9.07 \%$ urban households are still dependent on kerosene oil for lightening their houses. Contribution of solar power in the urban space is very low about $0.17 \%$ of total power consumption. In 2008-09 the rate of energy consumption was $734 \mathrm{KW} / \mathrm{h}$. which has increased by $1075 \mathrm{KW} / \mathrm{h}$ in $2015-16$. Per capita power consumption of the Ranchi city is increasing by $6 \%$ per year.

Cooking Fuel: The share of LPG is about $62.96 \%$ in urban region where as the contribution of the other fuel for cooking is $0.73 \%, 0.15 \%$ and $0.28 \%$ of kerosene, electricity and biogas respectively.

Slum: As per Ranchi Municipal Corporation (RMC) OUT OF 55 Wards 10 are dominated by slum dwellings. Corporation estimated approximately 3 lac. Slum dweller resides in the city of which $20 \%$ of households did not have toilet facilities. Whereas $50 \%$ of slum dwellers go for open defecation, because of lack of toilets, water supply etc.

Drainage: The urban space of Ranchi has only $29.4 \%$ of closed drainage connectivity for waste water outlet. The open drainage comprises $43.87 \%$, whereas in $26.73 \%$ of urban space has no drainage system.

Occupational Structure of the Urban Space Ranchi: The urban space comprises total working population $1,142,867$ in which $25.95 \%$ are main worker, $13.27 \%$ are marginal worker whereas $60.78 \%$ are non-workers. If we see the participatory ratio male and female, male comprises $49.77 \%$ while women shares only $28.11 \%$.

Categorical Wise Worker In Ranchi: Total cultivators 317,407 which comprises $27.78 \%$ whereas total agricultural labour consist 267360. Which comprises $23.39 \%$ working in household industries are 38452 in number and 3.36 in percentage. Other worker totals 519568 about $45.46 \%$ of total workers.

Traffic: traffic congestion is one of the emerging problems in Ranchi as huge mass of vehicles increased in past decade. The urban city Ranchi is well connected with NH-23, NH-33, and NH-75 as well as via rail routes and by air. Newly developed ring road is playing a vital role in tackling traffic situation in Ranchi City. Ring road is also at close proximity with the area based development region under the smart city mission of Ranchi.

\section{LAYOUT OF SMART CITY RANCHI}

The development of smart city Ranchi has two major components:-

A. Area Based Development and

B. Pan city development project.

Therefore Ranchi as a smart city would develop as a core as well as whole city simultaneously.

Area Based Development (ABD): The main purpose of $\mathrm{ABD}$ is to create of vibrant economy for the city and to address the socio- economic need of the resident in the core and Ranchi city as whole.

The ABD envisages development of a green field encumbrance free land of 656 acres. This area is well within the municipal core within $5 \mathrm{~km}$ distance from CBD and close proximity to the proposed capital complex, airport and Hatia railway station.

\begin{tabular}{|c|c|c|c|}
\hline Land use for ABD & $\begin{array}{c}\text { Area In } \\
\text { acres }\end{array}$ & $\begin{array}{c}\text { Percentage } \\
(\%)\end{array}$ \\
\hline 1. & $\begin{array}{c}\text { Open space \& } \\
\text { circulation } \\
\text { (Green/roads/open } \\
\text { areas) }\end{array}$ & 245 & 38 \\
\hline 2. & Institutional & 134 & 20 \\
\hline 3. & Residential & 86 & 13 \\
\hline 4. & Mix use components & 69 & 11 \\
\hline 5. & Commercial & 67 & 10 \\
\hline 6. & $\begin{array}{c}\text { Public \& Semi } \\
\text { public }\end{array}$ & 55 & 8 \\
\hline & Total & 656 & 100 \\
\hline
\end{tabular}

Key Map of Area Based Development Plan for Ranchi Smart City

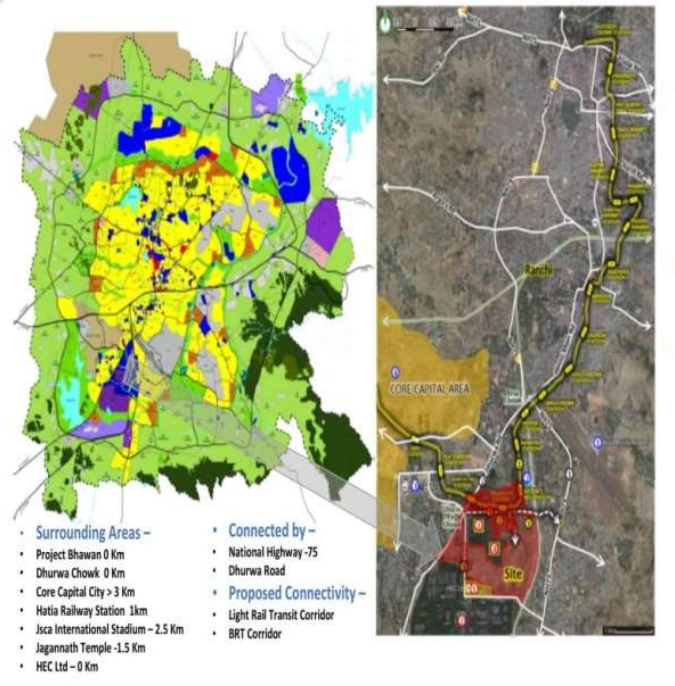


Zoning of Layout Plan of Area Based Development Site for Ranchi Smart City

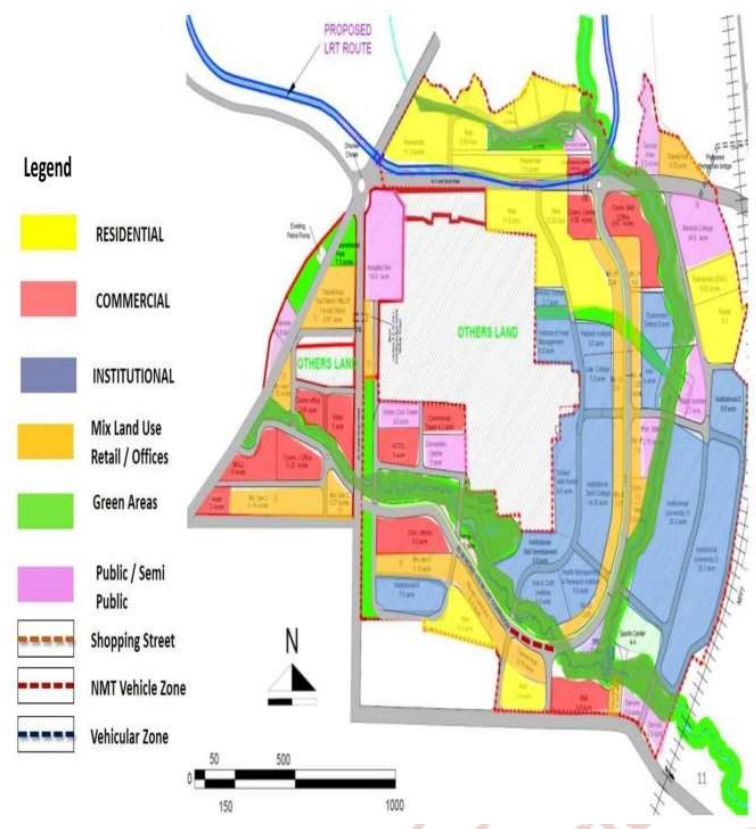

Pan City Development Project: For whole Ranchi city development it comprises integrated traffic and transport system (RITTS) is to be developed. Traffic control through information communication technology (ICT). It will provide digital platform for integrating public transport management, parking management, and corridor management, fare management along with integration with $A B D$ transport and traffic need.

\section{Major Aspects of Smart City Ranchi}

A. It will work as a knowledge hub for educational excellence.

B. Information communication technology based traffic system will efficiently manage the traffic.

C. Offers opportunities to the investors in areas of real estate, health education, housing and hospitality.

D. It will be designed to cater for all the basic amenities like good quality of drinking water, solid based management system, electricity supply, scientific sewerage and drainage system, IT connectivity, digitization, e-governance and participation.

E. Smart city ensures physical infrastructure like intelligent public transport, $24 \times 7$ smart water supply, zero emission, connectivity infrastructure, commercial hubs, convention centers and hotels.

F. It ensures social infrastructures like housing development, educational infrastructure, cultural and fitness centers park and river front development.
G. In economic infrastructure skill development centers, incubation centres, transit hub, commercial centers and banking centers would be developed.

H. In intuitional infrastructure e-governance and $\mathrm{m}$ governance, ease of doing business, minimum government and maximum governance, safety and security citizen engagement, disaster management are given more emphasis.

\section{Financial Structure For Smart City Ranchi}

Under the smart city mission 100 cities across the country will be developed as smart city by $2019-20$ with the union government providing financial support to the extent of rupees 48,000 crore over 5 years.

While 20 smart cities were selected during 2015-16 another 40 would be selected during 2016-17 and remaining 40 during the next financial year. Each city selected in different rounds of competitions will be given central assistance of rupees 200 crore in the first year and rupees 100 crores each during the subsequent 3 financial year.

State government and respective urban local bodies will also provide the same amount. Total cost of the smart city project of Indian cities is 203,172 crores in which 164204 crores will be used for area development which shares $80.8 \%$ of the total cost of the projects whereas pan city development project will cost 38,914 crores. Its share is $19.2 \%$ of the total cost of the project.

The total population will be impacted by the smart city mission is $99,630,069$.

\section{APPRAISAL OF RANCHI SMART CITY WITH OTHER SMART CITIES OF THE WORLD}

China: Chinahas built some smart cities to accommodate its urban population in Guiyang, Wohan, Nanjing and Hefei. Some scholars term them as 'Ghost City' of china as these cities are left out with lesser inhabitants. China still investing in developing new smart cities. China allocated $\$ 322$ Billion for smart city development by 2025 .

Abudhabi: Abudhabi investing $\$ 22$ billion for developing smart cities for 40,000 residential in Arabian Desert. 
South Korea: South Korea's smart city is endowed with waste disposal system where refuse is sucked underground directly from people homes. Radio Frequency Identification (RFID) a tracking device fitted to cars to promote traffic signals to change route during periods of congestion and a video call tell presence screen fitted in every office and shopping center.

U.S.A: In Boston smart city gunshot sensor is fitted on the crowded place. Whenever there is a gun shooting in the region, sensor automatically alerts the local police.

In Lowa smart city, smart water meter is fitted in each household which can be helpful for comparison with neighbour's water uses and accordingly will help in water conservation.

Ireland: In Dublin smart city "parkya" app developed by IBM for fining out the available parking slots.

Denmark: In Copenhagen smart city the green wave cycling system coordinates traffic light so that cyclist who maintain a $20 \mathrm{~km} / \mathrm{h}$ travelling speed only see green traffic light all the way along their commute.

Paris: In Velib smart city has facilities of public bicycle sharing system.

India: India's first operational city is known as GIFT City (Gujarat International Finance Tec City), which developed between Ahmedabad and Gandhinagar. as a green field project includes feature like district cooling system, utility tunnel and automated vacuum waste collection.

Fund provided by center may be adequate and smooth but fund yearly shared by state may cause hurdle in completion of the smart city.

\section{CRITICISM}

1. Cyber terrorism or even a software bug can crash the public transport and electricity grid.

2. CCTV constant surveillance prone to misuse by an authoritarian government.

3. Smart maps, smart metered connection leads to advertisement spams.

4. People loose communication, family community values in smart phone with GPS and WiFi.

5. Sense of place is lost, all the streets and shops are identical like Song do (S. Korea).
6. Central role played by private Tec firms in smart cities.

\section{CONCLUSION}

Smart cities are about being innovative in how they are governed, innovative in the way how they allocate tax payers money, innovative in how they engage citizens in transforming the city driven to support innovative and creativity in local economy and yes innovative in the use of technology as tools to improve quality of life and improve efficiency.

The picture is clear from the appraisal that Ranchi has different scenario that of the other smart cities of the world. In spite of having some hurdles in emerging as a new urban space in the form of smart city .it is fantastic way forward to manage its man and material in its urban periphery.

Smart city Ranchi would prove to be a major thrust to tackle the issues like population congestion, problem of traffic , slums, civic amnestic problem, unemployment etc. one of the great thing about smart city is it will work as economy hub of the city.

\section{REFERENCE}

1. District Census Handbook, Ranchi (2011), series 21, part-XII, B.

2. Graziella, F. (2016), smart city: a geographical perspective, Romanian review on political geography, Nov.2016, vol. 18. Issue-2.

3. Singh, Kr. S, 2015, Inside Jharkhand, crown publication, p-387-397.

4. smartcities.gov.in/content/

5. udhd.jharkhand.gov.in/other/RSC.aspx

6. ranchimunicipal.net

7. www.giftgujrat.in

8. https://geospatialworlforum.org/2016/programgeospatial-gis-smart-cities-asp 